\title{
Some Heavy Metals Assessment of Bees Pollen Grains, Alexandria, Egypt
}

\author{
Talaat A. Hegazy ${ }^{1}$, M. Morsy ${ }^{2}$ and Nory Shibany ${ }^{1 *}$ \\ ${ }^{1}$ Environmental Science Department, Faculty of Science, Damietta University, Egypt. \\ ${ }^{2}$ Environmental Science Department, Faculty of Agriculture, Alexandria University, Egypt.
}

Received: 11 January 2017 /Accepted: 18 April 2017

*Corresponding author: nurilshebani@gmail.com

\begin{abstract}
Pollen grain samples collected from pollen trap are analyzed for $\mathrm{Pb}, \mathrm{Cd}, \mathrm{Zn}$, and $\mathrm{Cu}$ levels. The results showed that the levels of lead: $0.0028,0.136,0.0001,0.033,0.004,0.0263,0.001$ and 0.0426 (ppm) in Edku (A, B), Kafr-Eldawar (A, B), Nobaria (A, B), Abis2 (A, B) respectively. The highest concentration of lead $(0.136 \mathrm{ppm})$ from Edku (B) and the lowest level $(0.0001 \mathrm{ppm})$ from KafrEldawar (A) in 2015, while 2016, the maximum content of lead was recorded in Abis 2 (A) with a mean value of $0.2120 \mathrm{ppm}$ while the minimum content determined $(0.007 \mathrm{ppm})$ in Edku (B).

The highest levels of Cadmium was recorded from Al-Nobaria (B) with mean value of $0.1010 \mathrm{ppm}$ and the lowest mean was detected from Abis 2 (B) which had $(0.0510 \mathrm{ppm})$ during 2015, while 2016 the highest concentration of cadmium (0.084 ppm) from Edku (B), the lowest level (0.0171 ppm) from Kafr-Eldawar (B).

The pollen grain samples from Edku (B) recorded the highest level of Zinc with a mean value of 1.853 and the lowest level of Zinc (1.3044 ppm) from Kafr-Eldawar (A) during 2015, in 2016 the maximum content of Zinc (2.0538 ppm) while , the minimum content of Zinc (0.8048 ppm) from Abis 2 (B) and Nobaria (B) respectively.

The highest level of copper content was recorded in pollen grain samples collected from Nobaria (A) with mean value of $(3.018 \mathrm{ppm})$, the lowest level $(0.614 \mathrm{ppm})$ recorded in Abis 2 (B) during 2016, while, the maximum content of copper was determined from Abis 2 (B) with a mean value of (6.299 ppm) and minimum content was recorded (2.14 ppm) in Edku (A).
\end{abstract}

Keywords: Bees, heavy metals, pollen grains, Egypt.

\section{Introduction}

Pollen grains are the major source of proteins, fatty substances, minerals and vitamins. It is essential for growth of Larvae and young adult bees. Honeybees collecting pollen when visiting flowers for getting nectar. Once at hive, workers pack pollen into the comb, to prevent bacterial growth and delay pollen germination, phytocidal acid is added to the pollen as it is packed in to the comb.

Other enzymes produced by worker bees are also added which prevent an aerobic metabolism and fermentations there by enhancing longevity of the stored pollen. Once completely processed for 
storage, the pollen comb was referred to as beebread (Al Fonsus, 1933 and Haydak,1935)

Bee pollen is highly consumed around the world like a dietary supplement due to its nutritive value , Humans are interested in the knowledge of pollen loads botanical composition also due to their the therapeutically benefits (Komosinska et al., 2015). The heavy metals contents of pollen are variable, due to the factors like difference between the plant species, geographical area, and condition drying process. The accessibility of heavy metals for plants depends on soil reaction mineral colloids, soil humidity microbiological activity and organic matter content.

Organic matter especially humus compounds can form organic -metallic compounds with high mobility in soil solutions and with high availability for plants and pollen (Kabata and Pendias, 2001).

The heavy metals like $\mathrm{Fe}, \mathrm{Mn}, \mathrm{Cu}$, and $\mathrm{Zn}$ can be essential in small quantities for plants, animal and humans but became toxic on high quantities. Other heavy metals such $\mathrm{Cr}, \mathrm{Ni}, \mathrm{Pb}$, are very toxic (Gergen et al., 2006).

This study was carried out to assess some heavy metal levels e.g. Lead ( $\mathrm{Pb})$, Cadmium (Cd), Zinc $(\mathrm{Zn})$, and Copper $(\mathrm{Cu})$ in pollen grain samples collected from eight apiaries during the period from January 2015 to December 2016.

The apiaries situated at different four regions in El-Behera and Alexandria Governorates (Edku, Kafr-Eldawar, El-Nobaria and Abis2. Every region divided into two locations (A and $\mathrm{B}$ ) first location (A) studied apiary at middle of flora and the second apiary (B) near pollution sources.

\section{Material and methods}

Pollen analysis was carried out on 40 pollen samples from 8 apiaries situated at different locations of EL-Behera and Alexandria Governorates (Edku- , Kafr-EL-dawar, ELNabaria and Abis).

Every location divided into two apiaries, first apiary situated near the roads (main street) near pollution sources and the second apiary at middle of flora, pollen samples were collecting during the period from January 2015 to December 2016, this samples collected with pollen trap.

The heavy metals from bee pollen samples were analyzed by using dry a shing technique (Lssec and Kerber, 1971), one gram of sample in a crucible was placed in a preheated muffle furnace at $200-250^{\circ} \mathrm{C}$ for $30 \mathrm{~min}$., and then the sample was removed from the furnace and cooled down $0.5 \mathrm{ml}$ of $6 \mathrm{~N} \mathrm{HNO}_{3}$ (nitric acid solution) was added.

The solution was filtered through Whatman No.42 filter paper and $0.45 \mu \mathrm{m}$ Millipore filter paper, then transferred quantitatively to a $25 \mathrm{ml}$ nitric acid flack by adding distilled water.

The solution obtained were used for total heavy metals determination by Flame Atomic Absorption Spectrometry with high - resolution continuum source. Four metals were quantified for each pollen samples: Lead $(\mathrm{Pb})$, Cadmium $(\mathrm{Cd})$, Zinc(Zn), and Copper(Cu) .

Analysis of heavy metals was made with Varian, spectra AA-220, Analytic -Jena device, by flame atomic absorption spectrometry (F-AAS) in air / acetylene (high purity; 99.99\%) flame, the device working parameters (air, acetylene, optics and electronics) were adjusted for maximum absorption for each elements.

Under the optimum established parameters, standard calibration curves for metals were constructed by plotting absorbency against concentration. All the values obtained for metals contents in pollen samples were calculated in $\mathrm{ppm}$.

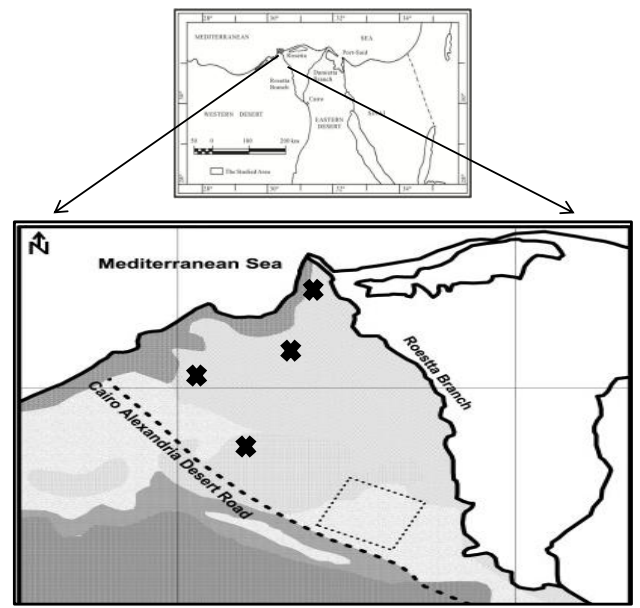

Fig. (1) Location sites of experimental apiaries

\section{Results and Discussion}

The results of this study were summarized in Table (1) and Table (2). The highest concentrations of $\mathrm{Pb}$ were recorded in pollen grain sampled from Edku (B), 2015, and Abis 2 (A), 2016, with mean value of $0.1360 \mathrm{ppm}$ and $0.2120 \mathrm{ppm}$ respectively, meanwhile the lowest mean concentration was recorded in Kafr-Eldawar (A) with a mean value of $0.0001 \mathrm{ppm}$ (2015), while (2016) was recorded in Edku (B) with a mean value of $0.007 \mathrm{ppm}$, followed by pollen 
from Abis 2 (B), (0.2109 ppm), Kafr-Eldawar (A), (0.024 ppm), Edku (A), (0.0211 ppm), Nobaria
(A), (0.0142 ppm), Kafr-Eldawar (B), (0.0091 ppm)and Nobaria (B), (0.0082 ppm).

Table 1: Mean values of Lead, Cadmium, Zinc, and Copper levels (ppm) in pollen grains samples from different regions of EL-Behera and Alexandria Governorates during year 2015.

\begin{tabular}{|c|c|c|c|c|c|c|}
\hline \multirow{2}{*}{ Governorate } & \multirow{2}{*}{ Regions } & \multirow{2}{*}{ Location } & \multicolumn{4}{|c|}{ Heavy Metals (ppm) } \\
\cline { 3 - 7 } & & & $\mathrm{Pb}$ & $\mathrm{Cd}$ & $\mathrm{Zn}$ & $\mathrm{Cu}$ \\
\hline \multirow{3}{*}{ EL-Behera } & \multirow{2}{*}{ Edku } & $\mathrm{A}$ & 0.0028 & 0.0079 & 1.4620 & 0.6990 \\
\cline { 3 - 7 } & \multirow{2}{*}{ Kafr-ELdawar } & $\mathrm{B}$ & 0.1360 & 0.0126 & 1.8530 & 1.2770 \\
\cline { 3 - 7 } & & $\mathrm{A}$ & 0.0001 & 0.095 & 1.3044 & 0.7851 \\
\cline { 3 - 7 } Alexandria & \multirow{2}{*}{ Nobaria } & $\mathrm{B}$ & 0.0033 & 0.0072 & 1.7672 & 1.1341 \\
\cline { 3 - 7 } & & $\mathrm{B}$ & 0.0004 & 0.0100 & 1.6603 & 3.018 \\
\cline { 3 - 7 } & \multirow{2}{*}{ Abis 2 } & $\mathrm{A}$ & 0.0263 & 0.1010 & 1.8229 & 0.0882 \\
\cline { 3 - 7 } & & $\mathrm{B}$ & 0.0426 & 0.0051 & 1.4970 & 0.6141 \\
\hline
\end{tabular}

Table (2) Means of Lead, Cadmium, Zinc and Copper levels (ppm) in pollen grains samples of different regions from EL-Behera and Alexandria Governorates during year 2016.

\begin{tabular}{|c|c|c|c|c|c|c|}
\hline \multirow{2}{*}{ Govern. } & \multirow{2}{*}{ Regions } & \multirow{2}{*}{ Location } & \multicolumn{4}{|c|}{ Heavy Metals ppm } \\
\cline { 3 - 7 } & & & $\mathrm{Pb}$ & $\mathrm{Cd}$ & $\mathrm{Zn}$ & $\mathrm{Cu}$ \\
\hline \multirow{3}{*}{ EL-Behera } & \multirow{2}{*}{ Edku } & $\mathrm{A}$ & 0.0211 & 0.0081 & 1.4332 & 2.1400 \\
\cline { 3 - 7 } & \multirow{2}{*}{ Kafr-ELdawar } & $\mathrm{B}$ & 0.0070 & 0.0840 & 1.720 & 2.9972 \\
\cline { 3 - 7 } & \multirow{2}{*}{ Alexandria } & $\mathrm{A}$ & 0.0240 & 0.0035 & 1.5644 & 5.5313 \\
\cline { 3 - 7 } & \multirow{2}{*}{ Nobaria } & $\mathrm{B}$ & 0.0091 & 0.0017 & 2.0046 & 5.0291 \\
\cline { 3 - 7 } & \multirow{2}{*}{ Abis 2 } & $\mathrm{B}$ & 0.0142 & 0.0033 & 0.9264 & 2.4612 \\
\cline { 3 - 7 } & & $\mathrm{A}$ & 0.2120 & 0.0035 & 1.5459 & 6.0862 \\
\cline { 3 - 7 } & $\mathrm{B}$ & 0.2109 & 0.0045 & 2.0538 & 6.2992 \\
\hline
\end{tabular}

All the values of $\mathrm{Zn}$ and $\mathrm{Cu}$ exceeded the polish permissible standard $(0.4-0.5 \mathrm{ppm})$, the accepted levels of lead in food $(0.3 \mathrm{ppm})$ and up to the national accepted limits in similar products (1.0 ppm) in Romania.

Lead is not an essential element for life and is considered a highly toxic trace element that causes many disturbances to plants and animals health, including man and environment (Chen et al., 2004). Some anther evaluated the degree of environmental pollution with lead on the basis of examination regarding bee and their products contaminations, including pollen. Konopacka et al. (1993) detected elevated lead concentration $(1.2 \mathrm{ppm})$ in pollen collected in farm experimental apiaries localized near a busy road in the regions of Pulway. However, Conti and Botre (2001), proved relatively low lead concentration in pollen ranging from $(0.020-0.332 \mathrm{ppm})$. Also, Harmaneseu et al. (2007) noticed that all the values obtained for lead contents were less than national accepted limits $(1.0 \mathrm{mg} / \mathrm{kg})$.

El-Naggar et al. (2013) observed that lead levels in pollen samples collected during summer from El-Mahala EL-Kobra, Kafr El-Sheikh and Kafr El-Zayat (10.53,13.85 and $10.13 \mathrm{ppm})$, respectively, considerably exceeded permissible standard, while, it was below the standard limit in Al-Fayoum (2.85 ppm).
The pollen grain samples from El-Nobaria (B) recorded the highest concentration of cadmium $(0.1010 \mathrm{ppm})$, followed by samples collected from Edku (B), Nobaria (A), and Abis 2 (A).

Kafr-Eldawar (A) and Kafr-Eldawar (B) with mean values of $(0.0126,0.0100,0.0097,0.0095$, $0.0072 \mathrm{ppm})$, respectively. While the lowest value $(0.0051 \mathrm{ppm})$ was detected in samples from Alexandria location (B) in year 2015. However, in 2016 maximum content of cadmium was detected from analyzed samples collected from Edku location (B) with mean value of $0.0084 \mathrm{ppm}$, while the minimum content was recorded in KafrEldawar location (B) with a mean values $(0.0017$ ppm).

The average concentration of the in samples $(0.019 \mathrm{ppm})$ significantly exceeded permissible standard it was 10 times highest than the polish and trade norms $(0.05 \mathrm{ppm})$ and about 5 times greater than the Norms and Kenya Bureau (2009) of standard limits in food products; $(0.1 \mathrm{ppm})$.

The highest level of Zinc with a mean value of $(1.853 \mathrm{ppm})$ was noticed in pollen grain samples collected from apiariey in Edku (B), followed by Nobaria (B): (1.8229 ppm), Kafr-Eldawar (B) (1.7672 ppm), Nobaria (A ) (1.6603 ppm), Abis 2 (B) (1.497 ppm), Edku (A) (1.462 ppm) and Abis 2 (A) (1.3523 ppm). However, The lowest level 
was recorded for in Edku location A. with mean value of $1.3044 \mathrm{ppm}$.

The estimated daily intake of Zinc for normal person not high $(1.52 \mathrm{mg} /$ diet $)$ and lower than the permissible limit recommended $(15 \mathrm{mg} / \mathrm{kg} /$ day $)$ by WHO (1994).

In the year 2016, the maximum content of $\mathrm{Zn}$ was recorded from Abis 2 (B) with mean value of $(2.0538 \mathrm{ppm})$, while the minimum was found in Nobaria (A), 0.9264 ppm.

Szezesna (2007) found that $\mathrm{Zn}$ was the highest in the samples from Korea with the average of (47.41 $\mathrm{ppm})$, while slightly low from Poland (36.8 ppm) and the lowest in the sample from China with average of (28.9 ppm). Al-Naggar et al. (2013) recorded that, the highest in the samples collected from Al-Foyoum Governorate, Egypt, with average $1.38 \mathrm{ppm}$

All values obtained for Zinc contents in the present study were within the national accepted limit for this metal in similar products $(60 \mathrm{mg} / \mathrm{kg})$ except from Romania Ministry of Public Health (Ordinancen 0.975, 1998)

In 2015, the highest concentration of copper has detected in pollen samples from Abis 2 (A) with a mean value of $0.6299 \mathrm{ppm}$. Main while, the lowest mean concentration was recorded from Edku (A), which had 0.214 ppm.

The second year 2016, the highest level of copper was recorded in Abis 2 (B) with mean value of (6.2991 ppm) and mean which the lowest mean concentration was recorded for Edku (A; 2.140 ppm).

Also, daily intake for copper by human was not high $(0.318 \mathrm{mg} / \mathrm{diet})$ and below permissible limits recommended by WHO (1994), (2-3 mg/kg/day). Comparable results for copper were reported by (Harmaneseu et al., 2007). They found that $\mathrm{Cu}$ levels ranged between (5.51- $12.07 \mathrm{ppm}$ ).

El-Naggar et al. (2013) reported the highest concentration levels of copper (24.18-22.28 ppm) and the lowest (1.96-0.95 ppm) were noticed as during spring and summer in pollen samples collected from Kafr-El-Sheikh and Kafr -ElZayat.

\section{References}

Alfonsus, E.D. (1993). Zum pollen Ver brauch des Bienevolkes, Archiv Futir Bienenkunde 14:220223.

Al-Naggar,Y.A.; Naiem, E.A.; Seif, A.l. and Mona, M.H. (2013). Honeybees and their products as a bio- indicator of environmental pollution with heavy metals. Malefera, 13 (26): 10-20 .

Gergen 1.; Gogoasal.; Dragan, S.; Moigradean, D. and Harmonescu, M. (2006). Heavy metal status in fruits and vegetables from anon- polluted area of Romania (Banat county). Metal elements in environment, Medicine and Biology, Garban Z., Dragon P.(Eds. Symp. Series ), Tome, Publishing House Eurobit, Timisora, 2006 , P 149-165 .

Harmanescu, M.; Popovici, D. and Gergen, I. (2007). Heavy metals contents of bees pollen from different locations of Romania Luer. St. med.Vet. Timisoara Vol. X1: 253-260.

Haydak, M.H. (1935). Brood rearing by honeybee confined to pure carbohydrate diet. J. economic Entomology. 29: 257-660.

Ordinance no 957 (1998) Maximum limits accepted for heavy metal in foods. Excerpt from Romanian Ministry of public health Ordinance no 975/1998.

PN- R - 78893 (1997) (Polish Standard). Pollen loads: The Journal of Norms and the Measures, nr 3/1997, Poz.6 [in Polish]; (Cited from Roman, 2009).

Roman, A. (2009). Concentration of chosen trace elements of toxic properties in bee pollen loads. Polish Journal of Environmental Studies, 18(2): 265-272.

Szezesna, T. (2007). Concentration of selected elements in honeybee - collected pollen J. of Apic. Science 51(1): 15-22.

World. Health Organization (WHO) (1994). Health guideline for the use of waste water in agriculture and aquaculture. Report of (WHO) Science group, world health organization, Geneva, Suitzer land. Tech. Rep. Sci. 778: 10. 